\title{
ALGAE ACID PHOSPHATASE AFFECTED BY TEN METALS AND ENZYMATIC PARAMETERS DETERMINATION IN PRESENCE OF MERCURY AND COPPER
}

CLAUDIO MARTÍN JONSSON*

LOURIVAL COSTA PARAÍBA**

HIROSHI AOYAMA***

\begin{abstract}
Acid phosphatases play important roles in algae metabolism such availability/recycling of inorganic phosphate and autophagic digestive processes. Chemicals released into the environment from agricultural activities and through industrial and urban wastes, may impair algae enzyme activity. The aim of this work was to evaluate the in vitro activation/ inhibition effect of ten metals, commonly present as contaminants in soil and water, on the acid phosphatase extracted from the green algae Pseudokirchneriella subcapitata. Results demonstrated that $\mathrm{Hg}, \mathrm{Al}, \mathrm{Mo}, \mathrm{Pb}$, Se and $\mathrm{Cd}$ inhibited the enzyme activity in 56.3, 54.5, 30.6, 25.5, 23.1 and $11.5 \%$, respectively. This corresponds to the maximum percentage of effect attained at the metal concentrations tested $(0.02-2.0 \mathrm{mM})$. On the other hand, $\mathrm{Cu}, \mathrm{Zn}, \mathrm{Ni}$ and $\mathrm{Cr}$ exhibited an increment on phosphatase activity equal to $95.5,87.6,77.6$ and $42.8 \%$, respectively. Kinetic parameters values were calculated for the metals that showed highest effects. Thus, $K \mathrm{i}$ (inhibition constant) and $\mathrm{Kd}$ (dissociation constant) values equal to 0.0400 and $0.0016 \mathrm{mM}$ were determined for $\mathrm{Hg}$ and $\mathrm{Cu}$, respectively. A noncompetitive inhibition mechanism was attributed to the former. Results improved the understanding of the basic events of the impact of metals at biochemical levels in primary producers organisms.
\end{abstract}

* Doutor em Biologia Funcional e Molecular, Laboratório de Ecotoxicologia e Biossegurança, Embrapa Meio Ambiente, Jaguariúna, SP (e-mail: jonsson@cnpma.embrapa.br).

** Doutor em Matemática Aplicada, Laboratório de Geotecnologias e Métodos Quantitativos, Embrapa Meio Ambiente, Jaguariúna, SP (e-mail: lourival@cnpma.embrapa.br).

*** Doutor em Ciências, Professor Titular, Departamento de Bioquímica, Universidade Estadual de Campinas, Campinas, SP (e-mail: aoyama@unicamp.br). 


\section{INTRODUCTION}

As a result of anthropogenic activities such as industrial processing and agriculture practices, metal pollution has become one of the most serious environmental problems. The main concern associated with the presence of these pollutants is due their immutable nature (ALKORTA et al., 2004). The transport of these chemicals from contaminated soils to water bodies, followed by the adverse effects to the biota, is a result of two mechanisms: waterborne runoff (EI KHALIL et al., 2008) and lixiviation (BONTEN, ROEMKENS \& BRUS, 2008). For example, the application of $\mathrm{Cu}$-based fungicides resulted into increased copper concentrations in agricultural soils. Copper migrating through contaminated soils poses a risk for water quality (KOMÁREK et al., 2009). Although the use of mercury has been reduced in the last decades, concentrations of this metal were found in sludges (TSAKOU, ROULIA \& CHRISTODOULAKIS, 2001; OLIVEIRA et al., 2007). Mercury presents in sludges used as fertilizier is prone to be transported to aquatic compartments after soil incorporation (SLOAN et al., 2001). Algae and aquatic invertebrates are able to accumulate the metal and transfer it to higher levels of the food chain (GORSKI et al., 2008; TSUI \& WANG, 2004).

Drainage of industrial and urban effluents are also responsible for the contamination of aquatic compartments by metals like Zn, Al, Fe and Zn (JORDÃO et al., 2002).

The potential toxicity of metals in water may have detrimental effects on biochemicals processes of aquatic organisms including algae, an important component of primary production and thus the entire aquatic food chain.

Algal acid phosphatase plays important roles in metabolism such as decomposing organic phosphates into free phosphates and organic compounds. Several other functions have been attributed to algal acid phosphatases such as participation in autophagic digestive processes, hydrolysis of phospholipid materials (COOPER, BOWEN \& LLOYD, 1974), fertilization (breakdown of plasmalemma and absorption of flagella) (BRATEN, 1975), releasing of inorganic phosphate from the extracellular medium (SOMMER \& BLUM, 1965) recycling of inorganic phosphate for its reassimilation (THEODOROU et al., 1991), endomembrane recycling (DOMOZYCH, 1989) and spore differentiation (TSEKOS \& SCHNEPF, 1991).

In this work, was compared the inhibitor/activator effect of ten metals on the acid phosphatase extracted from Pseudokirchneriella subcapitata. This unicellular chlorophyceae (green) alga, present in the aquatic and terrestrial compartments (KEDDY, GREENE \& BONNELL, 1995), has been widely used in studies of agriculture pollutants effects (JONSSON et al., 1998; MUNKEGAARD, ABBASPOOR \& CEDERGREEN, 2008) and recommended by regulatory national (GHERARDI-GOLDSTEIN et al., 1990; JONSSON and MAIA, 1999) and international (OECD, 1984) agencies as a test organism. Moreover, the investigation was focused on two selected metals that showed highest effects $(\mathrm{Hg}$ and $\mathrm{Cu})$ by determining enzymatic parameters of their inhibition and activity increase.

\section{MATERIAL AND METHODS}

\subsection{MATERIAL}

$p$-Nitrophenylphosphate ( $p$ NPP; code N-9389) was obtained from Sigma Chemical Co. (St. Louis, MO). Stock solutions of $\mathrm{Al}_{2}\left(\mathrm{SO}_{4}\right)_{3}, \mathrm{CdCl}_{2} \cdot 2 \mathrm{H}_{2} \mathrm{O}, \mathrm{CuSO}_{4} 5 \mathrm{H}_{2} \mathrm{O}, \mathrm{CrCl}_{3}, \mathrm{HgCl}_{2}$, 
$\mathrm{NaSeO} \cdot 5 \mathrm{H}_{2} \mathrm{O},\left(\mathrm{NH}_{4}\right)_{6} \mathrm{Mo}_{7} \mathrm{O}_{24} \cdot 4 \mathrm{H}_{2} \mathrm{O}, \mathrm{Ni}\left(\mathrm{NO}_{3}\right)_{2}, \mathrm{~Pb}\left(\mathrm{NO}_{3}\right)_{2}$ and $\mathrm{ZnCl}_{2}$ were prepared in Milli-Q water. All the other reagents were also AR grade.

\subsection{ORGANISMS AND GROWTH CONDITIONS}

Unicellular green algae Pseudokirchneriella subcapitata was maintained and subcultured in an inorganic liquid medium prepared as recommended by OECD (1984). Cultures were grown in $250 \mathrm{~mL}$ flasks sealed with cotton bungs and containing $200 \mathrm{~mL}$ of sterilized medium. The flasks were incubated in a controlled temperature chamber $\left(20 \pm 2^{\circ} \mathrm{C}\right)$ under a continuous white fluorescent light of 3,000-4,000 lux and manually shaken twice a day. Every 40-60 days, a new stock culture maintained at $4^{\circ} \mathrm{C}$ (in dark) was prepared by inoculating approximately $5 \times 10^{4}$ cells $\mathrm{mL}^{-1}$ (JONSSON \& AOYAMA, 2007).

\subsection{HARVESTING AND PREPARATION OF EXTRACTS}

All centrifugation procedures were carried out at $4^{\circ} \mathrm{C}$. Exponential phase organisms were harvested by centrifugation at 4,000 r.p.m. for 5 min in a Beckman J221 refrigerated centrifuge (rotor SER\# 7644, JA-20) and washed twice with $0.1 \mathrm{M}$ sodium acetate buffer, $\mathrm{pH}$ 5.0. The algae pellet ( $3,1 \mathrm{~g}$ wet weight) was suspended in $12.4 \mathrm{~mL}$ of $0.1 \mathrm{M}$ sodium acetate buffer $(1: 4 \mathrm{w} / \mathrm{v})$ and the cell suspension was submitted to the cell disruption procedure for phosphatase extraction as described previously (JONSSON and AOYAMA, 2007): the sample was frozen at $-20^{\circ} \mathrm{C}$, thawed at room temperature and submitted to a probe sonication at $0^{\circ} \mathrm{C}$ (ice bath) for $50 \mathrm{~s}$ followed by $20 \mathrm{~s}$ interval (1 cycle) with an amplitude of 70 (Vibra Cell, Sonics Materials Inc., $45 \mathrm{~mm}$ tipped probe). This procedure was repeated twice. The resultant cell disrupted suspension was centrifuged at 10,000 r.p.m. for 20 min and the supernatant fluid (extract) was used for acid phosphatase activity determination.

\subsection{ASSAY OF PHOSPHATASE ACTIVITY}

Acid phosphatase activity was routinely assayed at least in duplicate by incubating the enzyme with $p$ NPP as substrate and measuring the $p$-nitrophenol ( $p N P$ ) produced as previously described (PRAZERES, FERREIRA \& AOYAMA, 2004). The enzyme activity was determined in a final volume of $1 \mathrm{~mL}$ containing $0.1 \mathrm{M}$ sodium acetate buffer $(\mathrm{pH}$ 5.0) and $10 \mathrm{mM}$ substrate. After incubation for $40 \mathrm{~min}$ at $37^{\circ} \mathrm{C}$, the reaction was terminated by the addition of $1 \mathrm{~mL}$ of $1 \mathrm{M} \mathrm{NaOH}$. The $p N P$ released was measured at $405 \mathrm{~nm}$ in a UNICAM 8625 UVIVIS spectrophotometer. For the initial velocity (V) determination, the amount of $p N P$ produced was calculated using a molar extintion coefficient of $18,300 \mathrm{M}^{-1} \mathrm{~cm}^{-1}$ (CHAIMOVICH \& NOME, 1970). Units $(U)$ of enzymatic activity are defined as $\mu$ moles of $p N P$ released per min.

\subsection{EFFECT OF METALS CONCENTRATIONS}

The enzyme activity was determined in the absence (control) or in the presence of three concentrations $(0.02,0.2$ and $2.0 \mathrm{mM})$ for each metal. Before the determination of enzyme activities, the enzyme was preincubated for 20 minutes at $37^{\circ} \mathrm{C}$ in the presence of 
the metals ions. After this time, the reaction was initiated by the addition of $10 \mathrm{mM}$ substrate and incubated for 40 min as described previously.

Data were analyzed by One Way ANOVA module (conjoint analysis) of the Statgraphics ${ }^{\circledR}$ Plus Version 2 software package (STATGRAPHICS ..., 1995). A $p$ value $<0.05$ was considered as significant.

\subsection{ENZYMATIC PARAMETERS IN PRESENCE OF Hg AND Cu}

\subsubsection{Determination of the median effect concentration $\left(E c_{50}\right)$}

The compound concentration that promotes $50 \%$ of enzyme activity alteration $\left(E C_{50}\right)$ and its $95 \%$ confidence limits was calculated by adjusting the regression curve data (\% activity vs. concentration) from enzyme activity at $13-15$ doses of each pollutant. The results were analyzed by a Simple Regression program with a Statgraphics ${ }^{\circledR}$ Plus Version 2 software package (STATGRAPHICS..., 1995).

\subsubsection{Kinetics constants}

- Inhibition constant (Ki)

Enzyme was assayed at eight concentrations (0.03-10.0 mM) of $p$ NPP as substrate in the absence or in the presence of $\mathrm{Hg}$ at three concentrations. Lineweaver-Burk plot was fitted in order to demonstrate the kind of inhibition (competitive or non-competitive). This experiment was also performed in order to compare the inhibitor effect of the surfactant linear alkylbenzene sulphonate (LAS) and Hg (JONSSON, PARAIBA \& AOYAMA, 2009). The Enzyme Kinetics Module contained in the SigmaPlot software package was used to calculate the $K_{i}$ value (SIGMAPLOT..., 1993).

- Dissociation constant $(K d)$

Lineweaver-Burk plot was used to determine the Cu-enzyme dissociation constant by plotting the reciprocal of velocity versus the reciprocal of copper concentration $(1 /[\mathrm{Cu}])$, as described by DIXON and WEBB (1979). YOUNGS, SUNDARAMOORTHY \& GOLD (2000) have also applied this method to determine the dissociation constant for the Cd-Mn-peroxidase complex.

The results were analyzed by a Simple Regression program with a Statgraphics ${ }^{\circledR}$ Plus Version 2 software package (STATGRAPHICS..., 1995).

\section{RESULTS AND DISCUSSION}

\subsection{EVALUATION OF METAL EFFECTS}

When the enzyme was preincubated in the presence of the metals, the order of inhibition at the higher concentration tested was $\mathrm{Hg}>\mathrm{Al}>\mathrm{Mo}>\mathrm{Pb}>\mathrm{Se}>\mathrm{Cd}$. On the other hand, $\mathrm{Cu}, \mathrm{Zn}, \mathrm{Ni}$ and $\mathrm{Cr}$ exhibited an increment on phosphatase activity equal to 95.5, 87.6, 77.6 and $42.8 \%$, respectively (Table 1). ANOVA test showed that among the ten metals tested, half of them altered significantly $(p<0.05)$ the enzyme activity. Among these, only Cu demonstrated significantly activator effect at all the concentrations tested. 
TABLE 1 - METAL EFFECT ON $P$. subcapitata ACID PHOSPHATASE ACTIVITY

\begin{tabular}{cccc}
\hline \multicolumn{3}{c}{ Relative activity (\%) } \\
\hline Metal & $\mathbf{0 . 0 2} \mathbf{~ m M}$ & $\mathbf{0 . 2} \mathbf{~ m M}$ & $\mathbf{2} \mathbf{~ m M}$ \\
$\mathrm{Al}$ & $106.50(2.56)$ & $94.89(2.90)$ & $45.48(5.03)^{*}$ \\
$\mathrm{Cd}$ & $88.85(3.46)$ & $92.42(1.20)$ & $88.94(2.35)^{\mathrm{a}}$ \\
$\mathrm{Cu}$ & $159.62(31.62)^{*}$ & $195.46(25.42)^{*}$ & $153.85(37.06)^{*}$ \\
$\mathrm{Cr}$ & $104.04(7.53)$ & $104.80(7.17)$ & $142.84(2.13)^{*}$ \\
$\mathrm{Hg}$ & $80.27(4.83)$ & $62.29(5.80)$ & $43.66(9.15)^{*}$ \\
$\mathrm{Mo}$ & $104.49(10.66)$ & $112.38(9.93)$ & $69.39(2.40)$ \\
$\mathrm{Ni}$ & $109.37(5.32)$ & $147.14(8.68)$ & $177.58(5.41)$ \\
$\mathrm{Pb}$ & $97.06(4.35)$ & $98.35(1.98)$ & $74.48(6.23)$ \\
$\mathrm{Se}$ & $89.56(1.02)$ & $78.66(3.20)$ & $76.92(7.92)$ \\
$\mathrm{Zn}$ & $143.83(24.35)$ & $187.58(49.90)^{*}$ & $179.59(41.74)$ \\
\hline
\end{tabular}

Enzyme activity was determined as described in "Materials and methods", in the absence or in the presence of the pollutants at the indicated concentrations. The activity in the absence of these chemicals was considered as control (100\%). Each value of relative toxicity was based on duplicate analysis from two experiments. Values in parenthesis are standard deviations.

${ }^{a} \mathrm{Cd}$ was tested at $0.5 \mathrm{mM}$ instead $2 \mathrm{mM}$.

* Denotes statistically significant difference $(p<0.05)$ from the control.

\subsection{STUDIES WITH Hg AND Cu}

\subsection{1 $\mathrm{EC}_{50}$ Determination}

In order to calculate the $E C_{50}$ of inhibition for $\mathrm{Hg}$ and the $E C_{50}$ of activation for $\mathrm{Cu}$ experiments were performed at different concentrations of these pollutants with $10 \mathrm{mM} p \mathrm{NPP}$ as substrate.

When data from both metals were adjusted by linear regression they generated logarithmic-x model curves $(y=a+b \ln x)$ in which the activity decreased or increased in function of the concentration, respectively for $\mathrm{Hg}$ and $\mathrm{Cu}$. The calculated $E C_{50}$ and $95 \%$ confidence limits from the curves are shown in Table 2.

Figure 1 shows the effect $\mathrm{Cu}$ concentration in non-preincubated and preincubated system demonstrating the increase of activity only for the last system. Such difference was not observed for the inhibition by Hg where the non-preincubated and the incubated samples did not promote appreciable difference in the degree of inhibition.

TABLE 2 - ENZYMATIC PARAMETERS FOR P. subcapitata ACID PHOSPHATASE IN PRESENCE OF Hg AND Cu

\begin{tabular}{lccc}
\hline \multicolumn{2}{c}{ Parameter } & $\mathbf{H g}$ & $\mathbf{C u}$ \\
\hline$E C_{50}(\mathrm{mM})$ & inhibition & $0.0850(0.0640-0.1170)^{\star}$ & - \\
$K i(\mathrm{mM})$ & activation & - & $0.0018(0.0016-0.0019)$ \\
$K d(\mathrm{mM})$ & & $0.0400(0.0280-0.0530)$ & - \\
\hline
\end{tabular}

*Values in parentheses are $95 \%$ confidence limits. 


\section{FIGURE 1 - ACID PHOSPHATASE ACTIVITY IN PRESENCE OF Cu}

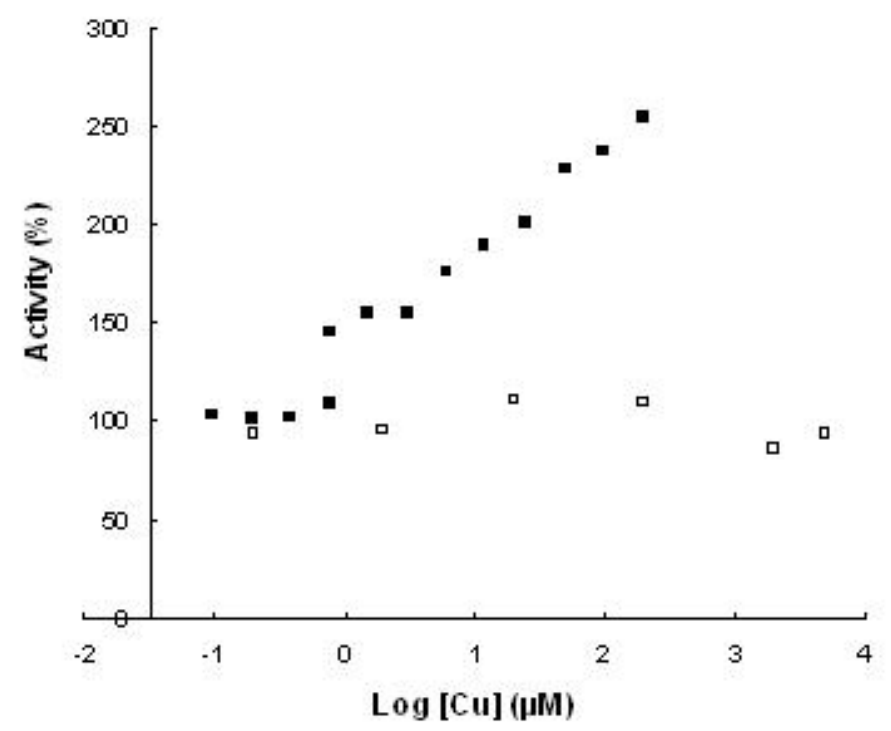

Phosphatase activity was measured at several $\mathrm{Cu}$ concentrations in preicubated ( $\boldsymbol{\square}$ ) and non-preicubated $(\square)$ tubes containing the enzyme plus the metal. In the former, enzyme was preincubated for 20 minutes at $37^{\circ} \mathrm{C}$ in the presence of the metal $\left(1^{\text {st }} \mathrm{step}\right)$. After this time, the reaction was initiated by the addition of $10 \mathrm{mM}$ substrate and incubated for $40 \mathrm{~min}$ ( $\left.2^{\text {nd }} \mathrm{step}\right)$. In non-preincubated system the $1^{\text {st }}$ step was not performed. The activities (\%) are relatives to the controls (without $\mathrm{Cu}$ ) activities which were considered as $100 \%$.

\subsubsection{Kinetic Constants}

The $K_{i}$ value (Table 2) for $\mathrm{Hg}$ was determined by nonlinear regression analysis from [S] versus $V$ curves at three concentrations of the pollutant agent. A non-competitive inhibition mechanism was obtained for $\mathrm{Hg}$ as showed in Figure 2.

The dissociation constant value for the complex Cu-enzyme is shown in Table 2.

In this work ten metals were tested in order to evaluate their in vitro effects on $P$. subcapitata acid phosphatase. Preincubation condition was used in order to verify the real effect on the enzyme avoiding any protection by the substrate that could occur in non pre-incubated system. Although the concentrations tested were higher than those present in environmental samples, the results of the screening study shown in Table 1 lead to choose the chemical agents that exhibited more powerful effects in order to conduct more specific studies. Mercury and copper demonstrated such behavior and allowed to determinate inhibition and activation parameters, respectively. The reason for chosen the former was due $\mathrm{Hg}$ was the most inhibitor at all the concentrations tested, followed by Al that showed notable inhibition only at the highest concentration tested. A comparative effect of five metals and LAS as inhibitors of the enzyme were previously reported (JONSSON, PARAIBA \& AOYAMA, 2009). Although $\mathrm{Zn}$ and $\mathrm{Cu}$ increased strongly the activity at similar range, it was selected the second for the complementary studies. This choice was due to the recognized high toxicity of $\mathrm{Cu}$ to algae species (LEVY et al., 2009) and because this metal, together with Cd and $\mathrm{Hg}$, has the lowest maximum concentration limit in aquatic compartments (CONAMA, 2005).

In previous works were showed the inhibitory modulation of $P$. subcapitata acid phosphatase activity by $\mathrm{Hg}$ in dependence on the metal concentration (JONSSON \& AOYAMA, 2007; JONSSON, PARAIBA\&AOYAMA, 2009). This work compares the enzymatic response by several inhibitors and activators metals in function of the concentration. 


\section{FIGURE 2 - LINEWEAVER-BURK PLOT FOR Hg NON-COMPETITIVE INHIBITION}

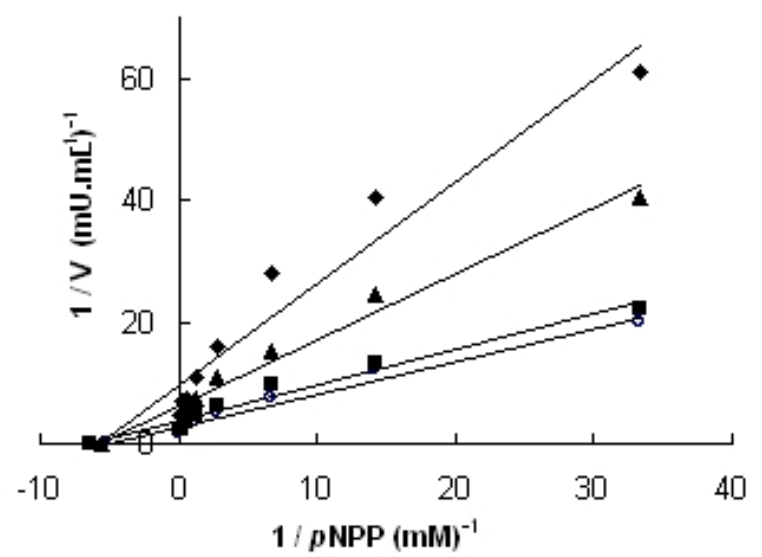

The enzyme activity was determined as described in "Materials and methods", at several substrate concentrations in the absence $(\mathrm{O})$, and in the presence of $0.01(\boldsymbol{\nabla}), 0.03(\mathbf{\Delta})$ and $0.13(\nabla) \mathrm{mM} \mathrm{Hg}$.

The degree of in vitro inhibition of phosphatases by $\mathrm{Hg}$ has been described for some organisms. According with PATNI and AARONSON (1974), the estimated concentration of $\mathrm{Hg}$ that inhibits $50 \%$ of algal acid phosphatase activity is close to that determined in the present work. This inhibition is of similar order of magnitude to that reported for the enzyme extracted from crabs (CHEN et al., 2000).

Essential -SH groups that would be present in the enzyme are able to interact with $\mathrm{Hg}$ and other heavy metals which can explain the observed inhibition (VAN ASSCHE \& CLIJSTERS, 1990). The substitution of an essential metal, which is deficient in the protein, by a toxic metal, would be another mechanism of inhibition (OMAR, 2002). Non-competitive inhibition promoted by $\mathrm{Hg}$ has been also described for other enzymes (WELLS, PAYTON \& PROUDFOOT, 1994; ARAUJO, SILVA \& HASSON-VOLOCH, 1996; SHUBO et al., 2001).

Copper ion has been generally known as an inactivator of enzymatic reactions systems, including acid phosphatases (GRANJEIRO et al., 1997; GRANJEIRO et al., 1999). In the presence of $\mathrm{Cu}$, the cleavage of $p N P P$ was increased when the metal was preincubated with the enzyme, as was demonstrated in this work. TSEKOVA and GALABOVA (2003) and BOUNIAS et al. (1996) also reported that $\mathrm{Cu}$ activated the acid phosphatase in crude extracts from fungi and insects. A preliminary study (data not showed) suggested that the metal protects the enzyme against thermal inactivation. This fact would explain the observed activation when the system is preincubated. The protection by copper and other metals against the inactivation of some enzyme was also documented (TROTMAN \& GREENWOOD, 1971; YOUNGS, SUNDARAMOORTHY \& GOLD, 2000; BALDRIAN \& GABRIEL, 2002).

\section{CONCLUSION}

Among the various metals tested, $\mathrm{Hg}$ and $\mathrm{Cu}$ exhibited higher degree of inhibition and increment of acid phosphatase activity, respectively. The former affected the enzyme in a non-competitive manner. In this inhibition mechanism, the presence of the inhibitor causes a change in the structure of the protein interfering with the enzyme-substrate affinity and consequently decreasing the hydrolysis velocity. 
The low $E C_{50}$ and $K d$ values demonstrated the high sensitivity of the enzyme crude extract to $\mathrm{Cu}$, as well as, the strong capacity in binding the metal. These properties would be useful as a tool to detect $\mathrm{Cu}$ in natural waters and other environmental samples if a method of extraction and concentration of the metal is available. Similar studies with $\mathrm{Zn}$ would be performed in order to determinate enzymatic parameters and evaluate its activator property as a promising biomarker. The results presented in this work increase the understanding of the mechanisms underlying impact of toxic metals at biochemical levels in primary producer organisms.

\section{RESUMO}

\section{EFEITO DE DEZ METAIS SOBRE A FOSFATASE ÁCIDA DE ALGA E DETERMINAÇÃO DE PARÂMETROS ENZIMÁTICOS NA PRESENÇA DE MERCÚRIO E COBRE}

O objetivo deste trabalho foi avaliar o efeito ativador/inibidor in vitro de dez metais, comumente presentes como contaminantes da água e solo, sobre a fosfatase ácida extraída da alga clorofícea Pseudokirchneriella subcapitata. Os resultados demonstraram que $\mathrm{Hg}, \mathrm{Al}, \mathrm{Mo}, \mathrm{Pb}$, Se e Cd inibiram a atividade enzimática em 56,3, 54,5, 30,6, $25,5,23,1$ e 11,5\%, respectivamente. Isto corresponde à porcentagem máxima de efeito atingida nas concentrações testadas $(0,02-2,0 \mathrm{mM})$. Por outro lado, $\mathrm{Cu}, \mathrm{Zn}$, Ni e Cr exibiram incremento na atividade fosfatásica equivalente a 95,5, 87,6, 77,6 e 42,8\%, respectivamente. Valores de parâmetros cinéticos foram calculados para os metais que evidenciaram maior efeito. Assim sendo, os valores de Ki (constante de inibição) e Kd (constante de dissociação) foram equivalentes a 0,0400 e 0,0016 mM, respectivamente para $\mathrm{Hg}$ e Cu. Mecanismo de inibição não competitiva foi atribuído para o primeiro. Os resultados enriquecem a compreensão de eventos básicos associados a impactos de metais em níveis bioquímicos de produtores primários.

PALAVRAS-CHAVE: ENZIMA; FITOPLANCTON; POLUENTES; Pseudokirchneriella subcapitata; TOXICIDADE.

\section{REFERENCES}

1 ALKORTA, I.; HERNÁNDEZ-ALLICA, J.; BECERRIL, J.M.; AMEZAGA, I.; ALBIZU, I.; GARBISU, C. Recent findings on the phytoremediation of soils contaminated with environmentally toxic heavy metals and metalloids such as zinc, cadmium, lead, and arsenic. Reviews in Environmental Sciences and Biotechnology, Dordrecht, v.3, p.71-90, 2004

2 ARAUJO, G.M.; SILVA, C.B.; HASSON-VOLOCH, A. Comparison of the inhibitory effects of mercury and cadmium on the creatine kinase from Electrophorous electricus $(\mathrm{L})$. The International Journal of Biochemistry and Cell Biology, Exeter, v.28, p.491-497, 1996.

3 BALDRIAN, P.; GABRIEL, J. Copper and cadmium increase laccase activity in Pleurotus ostreatus. FEMS Microbiology Letters, Amsterdam, v.206, p. 69-74, 2002.

4 BONTEN, L.T.C.; ROEMKENS, P.F.A.M.; BRUS, D.J. Contribution of heavy metal leaching from agricultural soils to surface water loads. Environmental Forensics, London ,v.9, p.252-257, 2008.

5 BOUNIAS, M.; KRUK, I.; NECTOUX, M.; POPESKOVIC, D. Toxicology of cupric salts on honeybees. V. Gluconate and sulfate action on gut alkaline and acid phosphatases. Ecotoxicology and Environmental Safety, New York, v.35, p.67-76, 1996.

6 BRATEN, T. Ultraestructural localization of phosphohydrolases in gametes, zygotes and zoospores of Ulva mutabilis FØYN. Journal of Cell Science, London, v.17, p.647-653, 1975.

7 CHAIMOVICH, H.; NOME, F. Purification and properties of an acid phosphatase from bovine brain. Archives of Biochemistry and Biophysics, New York, v.139, p.9-16, 1970.

8 CHEN, Q.X.; ZHENG, W.Z.; LIN, J.Y.; SHI, Y.; XIE, W.Z.; ZHOU, H.M. Effect of metal ions on the activity of green crab (Scylla serrata) alkaline phosphatase. International Journal of Biochemistry and Cell Biology, Exeter, v.32, p.879-885, 2000.

9 CONAMA. Conselho Nacional do Meio Ambiente. Resolução n. 357 de 17 de março de 2005. Diário Oficial [da] Republica Federativa do Brasil, Brasília, 2005. 
10 COOPER, A.; BOWEN, I.D.; LLOYD, D. The properties and subcellular localization of acid phosphatases in the colourless alga Polytomella caeca. Journal of Cell Science, London , v.15, p.605-618, 1974.

11 DIXON, M.; WEBB, E.C. Enzymes. $3^{\text {rd }}$ ed. London: Longmans Green, 1979.

12 DOMOZYCH, D.S. The endomembrane system and mechanism of membrane flow in the green alga, Gloeomonas kupfferi (Volvocales, Chlorophyta) II. A cytochemical analysis. Protoplasma, New York, v.149, p.108-119, 1989.

13 EL KHALIL, H.; EL HAMIANI, O.; BITTON G.; OUAZZANI, N.; BOULARBAH, A. Heavy metal contamination from mining sites in South Morocco: monitoring metal content and toxicity of soil runoff and groundwater. Environmental Monitoring and Assessment, Dordrecht, v.136, p.147-160, 2008.

14 GHERARDI-GOLDSTEIN, E.; BERTOLETTI, E.; ZAGATTO, P.A.; ARAÚJO, R.P.A.; RAMOS, M.L.L.C. Procedimentos para a utilização de testes de toxicidade no controle de efluentes líquidos. São Paulo: CETESB Secretaria do Meio Ambiente, 1990. (Série Manuais).

15 GORSKI, P.R.; ARMSTRONG, D.E.; HURLEY, J.P.; KRABBENHOFT, D.P. Influence of natural dissolved organic carbon on the bioavailability of mercury to a freshwateralga. Environmental Pollution, Barking, v.154, p. 116-123, 2008.

16 GRANJEIRO, J.M.; FERREIRA, C.V.; JUCA, M.B.; TAGA, E.M.; AOYAMA, H. Bovine kidney low molecular weight acid phosphatase: FMN-dependent kinetics. Biochemistry and Molecular Biology International, Marrickville, v.41, p.1201-1208, 1997.

17 GRANJEIRO, P.A.; FERREIRA, C.V.; GRANJEIRO, J.M.; TAGA, E.M.; AOYAMA, H. Purification and kinetic properties of a castor bean seed acid phosphatase. Physiologia Plantarum, Copenhagen, v.107, p.151-158, 1999.

18 JONSSON, C.M.; AOYAMA, H. In vitro effect of agriculture pollutants and their joint action on Pseudokirchneriella subcapitata acid phosphatase. Chemosphere, Oxford, v.69, p.849-855, 2007.

19 JONSSON, C.M.; MAIA, A.H.N. Protocolo de avaliação de agentes microbianos de controle biológico de pragas para registro como biopesticidas. III Testes em organismos não alvo do ambiente aquático. Jaguariúna: Embrapa Meio Ambiente, 1999. 33 p. (Série Documentos).

20 JONSSON, C.M.; MAIA, A.H.N.; FERREIRA, C.J.A.; RIBEIRO, E.O. Risk assessment of the herbicide clomazone to aquatic life. Verhandelingen International Verein Limnology, Stuttgart, v.26, p.1724-1726, 1998.

21 JONSSON, C.M.; PARAIBA L.C.; AOYAMA, H. Metals and linear alkylbenzene sulphonate as inhibitors of the algae Pseudokirchneriella subcapitata acid phosphatase activity. Ecotoxicology, London, v. 18, p. 610-619, 2009.

22 JORDÃO, C.P.; PEREIRA, M.G.; BELLATO, C.R.; PEREIRA, J.L.; MATOS, A.T. Assessment of water systems for contaminants from domestic and industrial sewages. Environmental Monitoring and Assessment, Dordrecht, v. 79, p.75-100, 2002.

23 KEDDY, C.J.; GREENE, J.C.; BONNELL, M.A. Review of whole organism bioassays: soil, freshwater sediment, and freshwater assessment in Canada. Ecotoxicology and Environmental Safety, New York, v.30, p.221-251, 1995.

24 KOMÁREK, M. ; VANEK, A.; CHRASTNÝ, V.; SZÁKOVÁ, J.; KUBOVÁ K., DRAHOTA, P.; BALÍK, J. Retention of copper originating from different fungicides in contrasting soil types. Journal of Hazardous Materials, Amsterdam, v.166, p.1395-1402, 2009.

25 LEVY, J.L.; STAUBER, J.L.; WAKELIN, S.A.; JOLLEY, D.F. The effect of bacteria on the sensitivity of microalgae to copper in laboratory bioassays. Chemosphere, Oxford, v.74, p.1266-1274, 2009.

26 MUNKEGAARD, M.; ABBASPOOR, M.; CEDERGREEN, N. Organophosphorous insecticides as herbicide synergists on the green algae Pseudokirchneriella subcapitata and the aquatic plant Lemna minor. Ecotoxicology, London, v.17, p.29-35, 2008.

27 OECD. Organization for Economic Cooperation and Development. Guidelines for testing of chemicals. Alga, growth inhibition test. Paris, 1984. 
28 OLIVEIRA, A.D.; BOCIO, A.; TREVILATO, T.M.B.; TAKAYANAGUI, A.M.M.; DOMINGO, J.L.; SEGURA-MUÑOZ, S.I. Heavy metals in untreated/treated urban effluent and sludge from a biological wastewater treatment plant. Environmental Science and Pollution Research, Heidelberg, v.14, p.483-489, 2007.

29 OMAR, H.H. Bioremoval of zinc by Scenedesmus obliquus and Scenedesmus quadricauda and its effects on growth and metabolism. International Biodeterioration and Biodegradation, Barking, v.50, p.95-100, 2002.

30 PATNI, N.J.; AARONSON, S. Partial characterization of the intra- and extracellular acid phosphatase of an alga, Ochromonas danica. Journal of General Microbiology, London ,v.83, p.9-20, 1974

31 PRAZERES, J.N.; FERREIRA C.V.; AOYAMA, H. Acid phosphatase activities during the germination of Glycine max seeds. Plant Physiology and Biochemistry, Paris, v.42, p.15-20, 2004.

32 SHUBO, H.; MIN, Z.; ZHUOBIN; Y.; XIN, L. A methylene blue mediated enzyme electrode for the determination of trace mercury (II), mercury (I), methylmercury, and mercury glutathione complex. Biosensors and Bioelectronics, Essex, v.16, p.9-16, 2001.

33 SIGMAPLOT scientific graphing software. San Rafael, CA: Jandel Scientific, 1993.

34 SLOAN, J.J.; DOWDY R.H.; BALOGH, S.J.; NATER, E. Distribution of mercury in soil and its concentration in runoff from a biosolids-amended agricultural watershed. Journal of Environmental Quality, Madison, v.30, p.173-2179, 2001.

35 SOMMER, J.R.; BLUM, J.J. Cytochemical localization of acid phosphatase in Euglena gracilis. Journal of Cell Biology, New York, v.24, p.235-251, 1965.

36 STATGRAPHICS Plus Version 2.0 for Windows: user manual. Rockville: Manigistics, 1995.

37 THEODOROU, M.E.; ELRIFI, I.R.; TURPIN, D.H.; PLAXTON, W.C. Effect of phosphorus limitation on respiratory metabolism in the green algae Selenastrum minutum. Plant Physiology, Minneapolis, v.95, p.1089-1095, 1991.

38 TROTMAN, N.A.; GREENWOOD, C. Effects of zinc and other metal ions on the stability and activity of Escherichia coli alkaline phosphatase. The Biochemical Journal, London, v.124, p.25-30, 1971.

39 TSAKOU, A.; ROULIA, M.; CHRISTODOULAKIS, N.S. Growth of cotton plants (Gossypium hirsutum) as affected by water and sludge from a sewage treatment plant: II. Seed and fiber yield and heavy metal accumulation. Bulletin of Environmental Contamination and Toxicology, New York, v.66, p.743-747, 2001.

40 SEKOS, I.; SCHNEPF, E. Acid phosphatase activity during spore differentiation of the red algae Gigartina teedii and Chondria tenuissima. Plant Systematics and Evolution, New York, v.176, p.35-51, 1991.

41 TSEKOVA, K.; GALABOVA, D. Phosphatase production and activity in copper (II) accumulating Rizopus delemar. Enzyme and Microbial Technology, New York, v.33, p.926-931, 2003.

42 TSUI, M.T.; WANG, W.X. Uptake and elimination routes of inorganic mercury and methylmercury in Daphnia magna. Environmental Science \& Technology, Easton, v.38, p.808-816, 2004.

43 VAN ASSCHE, F.; CLIJSTERS, H. Effect of metals on enzyme activity in plants. Plant Cell and Environment, Oxford, v.13, p.195-206, 1990.

44 WELLS, T.N.; PAYTON, M.A.; PROUDFOOT, A.E. Inhibition of phosphomannose isomerase by mercury ions. Biochemistry, Washington, v.33, p.7641-7646,1994.

45 YOUNGS, H. L. ; SUNDARAMOORTHY, M. ; GOLD, M. H. Effects of cadmium on manganese peroxidase. Competitive inhibition of Mnll oxidation and thermal stabilization of the enzyme. European Journal of Biochemistry, Berlin, v.27, p.1761-1769, 2000.

\section{ACKNOWLEDGEMENTS}

This work was supported by Fundação de Amparo à Pesquisa do Estado de São Paulo (FAPESP), Conselho Nacional de Desenvolvimento Científico e Tecnológico (CNPq) and Empresa Brasileira de Pesquisa Agropecuária (EMBRAPA). 